\title{
The role of follicular helper CD4 T cells
} in the development of HIV-1 specific broadly
neutralizing antibody responses

\author{
Eirini Moysi, Constantinos Petrovas ${ }^{*}$ (D) and Richard A. Koup
}

\begin{abstract}
The induction of HIV-1-specific antibodies that can neutralize a broad number of isolates is a major goal of HIV-1 vaccination strategies. However, to date no candidate HIV-1 vaccine has successfully elicited broadly neutralizing antibodies of sufficient quality and breadth for protection. In this review, we focus on the role of follicular helper CD4 T-cells (Tfh) in the development of such cross-reactive protective antibodies. We discuss germinal center (GC) formation and the dynamics of Tfh and GC B cells during HIV-1/SIV infection and vaccination. Finally, we consider future directions for the study of Tfh and offer perspective on factors that could be modulated to enhance Tfh function in the context of prophylactic vaccination.
\end{abstract}

Keywords: Germinal center, Tfh, Broadly neutralizing antibody, Vaccines

\section{Background}

A sterilizing HIV-1 vaccine would greatly facilitate the fight against the HIV-1 epidemic. Research efforts over the past 35 years have afforded unique insights into the biology, virology and immunology of HIV-1 infection including a better appreciation of the importance of cross-clade reactive, broadly neutralizing antibodies (bnAbs) $[1,2]$. HIV-1 is a highly diverse pathogen and successfully evades immunity by constantly shifting its antigenicity through evolution [3]. The failure of the Merck adenovirus type 5 (Ad5)-based vaccine in the STEP trial to induce robust protective cell-mediated immunity (CMI) responses to either prevent HIV-1 infection or suppress viral load in infected individuals refocused vaccine development efforts on humoral immunity [4]. bnAbs are antibodies that recognize highly conserved sites of vulnerability in many different circulating strains of HIV-1 $[5,6]$. As such, they hold great promise for HIV-1 vaccine development. Studies of passive bnAb transfer in non-human primates and humans have been shown to prevent infection and reduce viral loads,

*Correspondence: petrovasc@mail.nih.gov

Immunology Laboratory, Vaccine Research Center, NIAID, NIH, Bethesda, USA

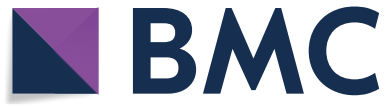

(c) The Author(s) 2018. This article is distributed under the terms of the Creative Commons Attribution 4.0 International License (http://creativecommons.org/licenses/by/4.0/), which permits unrestricted use, distribution, and reproduction in any medium, provided you give appropriate credit to the original author(s) and the source, provide a link to the Creative Commons license, and indicate if changes were made. The Creative Commons Public Domain Dedication waiver (http://creativecommons.org/ publicdomain/zero/1.0/) applies to the data made available in this article, unless otherwise stated. 


\section{Tfh cells and their role in GC responses}

Tfh are cells that localize to the lymph nodes, within well-defined structures called B-cell follicles (Fig. 1) [20, 21]. They are critical for the maturation, isotype switching, and somatic hypermutation (SHM) of B cells as well as for the survival of memory B cells and antibodysecreting plasma cells $[20,22,23]$. Their role thus is instrumental for the generation of high affinity antibodies. Tfh cells express low levels of CCR7 and are classically defined by the expression of the surface receptors CXCR5 and costimulatory receptors PD-1 and ICOS [20]. Their unique phenotype is preserved among different species including mice [24], non-human primates [25] and humans [21]. Although their ontogeny is not entirely clear, Tfh cells share characteristics with other CD4 T-cell lineages [26, 27]. However, their transcriptional regulation and gene expression profiles are distinct from all other lineages such as Th1, Th2, Th17 and regulatory $\mathrm{T}$ cells $[28,29]$. Maturation of Tfh cells begins with antigen priming by DCs in the $\mathrm{T}$ cell zones surrounding the lymphoid follicles [30] and continues at the follicular T-B border with cognate interactions between Tfh and B-cells [31, 32]. These events lead to the induction of the transcription factor Bcl-6 as well as c-Maf that control lineage commitment to the Tfh fate [33, 34]. These early Tfh-B cell interactions require expression of the surface receptors ICOS, OX40 and CD40-ligand as well as expression of the cytokines IL-4 and IL-21 and have been shown to influence both Tfh fate commitment and the survival and ability of B cells to enter the GC response [29, 35-37]. B-cells activated during these early Tfh-B cell cognate interactions can subsequently move in extrafollicular areas for proliferation and differentiation into short-lived, antibody-secreting plasma cells or migrate into B cell follicles to establish a GC [38]. What determines either fate is not entirely clear but evidence exists to suggest that the decision might be contingent on the affinity of the $\mathrm{B}$ cell receptor (BCR) for the foreign antigen $[39,40]$, the density of antigen-MHC class II complex engagement [41], and the costimulatory signals received from $\mathrm{T}$ cells [38]. In these early steps of GC formation, the relative density of MHC class II expression on $\mathrm{B}$ cells appears to reflect the affinity of a given BCR precursor for antigen and the efficiency of BCR-mediated antigen uptake [42]. Thus, early cognate Tfh-B cell interactions may represent an important bottleneck in the ability of Tfh to recruit $B$ cells of a given specificity into the response [43]. The follicular recruitment, frequency and function of Tfh, is additionally influenced by the relative abundance of antigen and availability of chemokines such as CXCL13 and SDF-1 [44]. In the GC, B cells constantly migrate between the light zone (LZ) and the dark zone (DZ) and thus the process of GC selection is highly regulated spatiotemporally [45]. T cell help in the LZ has been shown to activate the mTORC1 pathway, promoting a phase of anabolic growth that precedes and sustains the successive cycles of DZ proliferation [46]. Thus, Tfh in the $\mathrm{LZ}$ determine the cycling speed and number of cell divisions that a GC B cell will undergo as well as the associated number of $B$ cell receptor (BCR) mutations in the GC per round of selection [43, 47, 48]. These data suggest that optimal GC reactivity and bnAb development depend on the phenotype of Tfh, as well as their spatiotemporal localization.

\section{HIV-1/SIV infection and bnAb development Role of Tfh cell quality}

HIV-1/SIV infection and the resulting viremia influence the signals and mechanisms that regulate the dynamics of Tfh cells as well as the dynamics of Tfh-GC B cell interaction in LN follicles. Tfh induction can be traced as early as 14 days post-infection in NHPs challenged with SIV [49] and studies in humans and NHPs show that despite CD4 $\mathrm{T}$ cells being depleted during chronic HIV-1/SIV infection, the frequency of CXCR5 + PD- $1^{\text {hi }}$ CD4 $\mathrm{T}$ cells significantly increases both in the blood as well as in the LNs [50-53]. However, the increase in the frequencies of Tfh is not directly translated into higher bnAb levels. Only $20-30 \%$ of infected individuals are capable of mounting broadly neutralizing antibodies with HIV-1-specificities that have the potential to bind multiple HIV-1 envelope spikes of heterologous lineage during the first three years of infection [54]. Why some individuals and animals are able to develop bnAbs in the context of viremia whereas others do not is not entirely clear but both virologic, genetic and immunologic factors seem to influence this outcome. Virologic parameters that have been linked to bnAb production include characteristics of the infecting strain (ie viral loop length) [55-57] and degree of viral diversity [56]. For instance, exposure to multiple variants, as in the case of superinfection, has been shown to predict the development of bnAbs $[56,58]$ and studies in NHP and humans point to antigenic diversity (ie Env) being an important parameter with high viral loads and greater sequence evolution predicting a greater breadth of neutralization $[56,58,59]$. Host genetic factors, such as expression of specific HLA alleles have also been associated with bnAb activity in some cohorts [60, 61] whereas from an immunological stand-point, two parameters considered important are the ability of Tfh cells to provide help to B cells [62] and level of T-cell regulation [63].

CD4 $\mathrm{T}$ cells in the LN are a major target for HIV-1 infection. CXCR5+ PD-1 ${ }^{\text {hi }}$ cells in infected LNs have been shown to harbor a significantly increased frequency of HIV-1 DNA compared with non-Tfh cells [52] and 

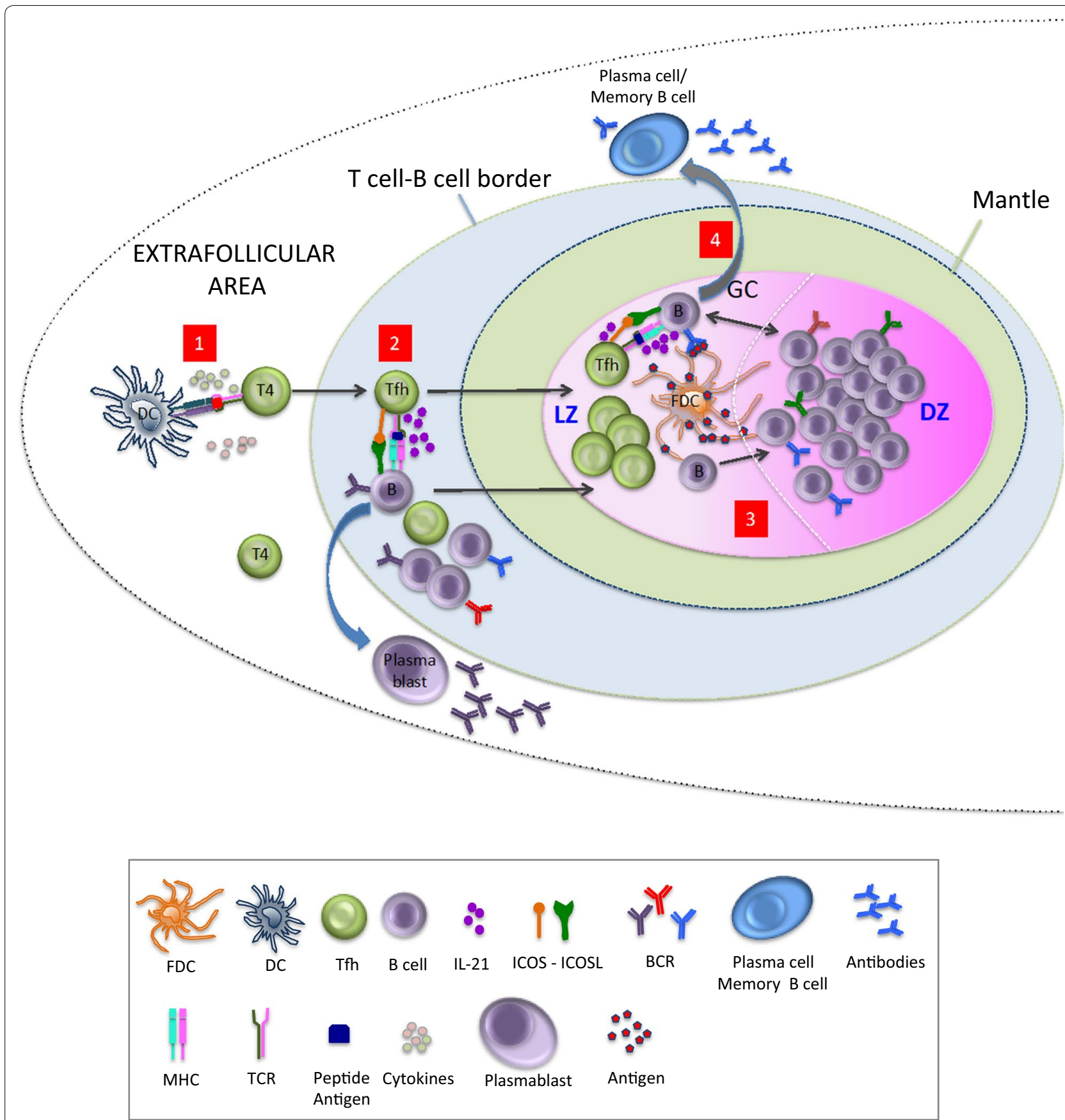

Fig. 1 Sequence of events leading to GC induction and the production of high affinity antibodies. (1) The induction of Tfh takes place in the T-cell zone upon interaction with DCs. (2) In the T-B border, B cells present antigen in complex with MHC-II to Tfh. These early cognate interactions determine which B cells will migrate to the GC to undergo somatic hypermutation and clonal expansion and which will become plasmablasts. (3) GC B cells constantly migrate between the LZ and DZ sampling antigen on FDCs and receiving help from Tfh. The nature of these interactions determines which GC B cells will survive and become plasma cells as well as the number of rounds of affinity maturation and somatic hypermutation a B cell will undergo before selection and exit to the periphery. (4) GC B cells become either antibody secreting plasma cells or memory B cells upon GC exit. Tfh, follicular T-helper cell; GC, germinal center; DC, dendritic cell; MHC, major histocompatibility complex; LZ, light zone; DZ, dark zone; FDC, follicular dendritic cell; BCR, B cell receptor; ICOS, Inducible T-cell costimulator; TCR, T cell receptor 
to represent a major reservoir of latent virus in humans receiving antiretroviral therapy $[64,65]$. In addition, their localization in close proximity to virion-ladden follicular dendritic cells (FDCs) in B cell follicles makes them increasingly susceptible to infection (Fig. 2) [66, 67]. Tfh cells isolated from HIV-1-infected patients produce less IL-21, a critical cytokine for GC formation, GC B cell proliferation and B cell maturation [68]. Exogenous administration of IL-21 has been shown to improve memory B cell frequencies, which suggests that IL-21 deficiency may, at least in part, impair the formation of memory B cell responses [69, 70]. HIV-1/SIV infection also imparts defects in the PD-1/PD-L1 axis. GC B cells from HIV-1 infected individuals express elevated levels of PD-L1 and have been shown to reduce ICOS and IL-21 expression in Tfh cells upon PD-1 ligation which could further compromise their ability to provide help to B cells [62]. The in vivo cycling capacity of Tfh cells is also compromised compared with other CD4 T-cell populations within the lymph nodes of infected NHP [53]. Moreover, in chronic untreated HIV-1+ infection Tfh become functionally skewed and oligoclonally restricted [71] Thus, HIV-1/SIV infection potentially alters the ability of Tfh to provide help to GC B-cells through a number of mechanisms. However, to what extend tissue-specific Tfh responses, including ICOS, CD40L expression and cytokine secretion differ between broadly neutralizers and non-neutralizers remains poorly understood. More recently, a number of studies have pointed to the heterogeneity of the Tfh population within the GC but less is known about the exact ontogeny of these individual phenotypes [72-74]. For instance, Tfh cells expressing CD57, show a significantly higher frequency of HIV-1 infection compared with extrafollicular CD4 T cells $[75,76]$ and transcriptional signatures that show differences when compared to CD57- [72]. Moreover, chronic SIV infection has been shown to promote expansion of CXCR3+ expressing, IFN- $\gamma$ producing GC Th cells (Th1-like) which are functionally distinct from CXCR3- Tfh in terms of phenotype and cytokine production [77]. To what extend these alterations affect the development of bnAbs is not currently known. Differences in the antigenspecificity or clonality of Tfh cells may also account for differences in the HIV-1-specific GC B-cell responses [71]. Even though the in vitro quantification of antigenspecific Tfh cells has been challenging [78] data supporting different roles for phenotypically distinct Tfh cells are available. In one study, IL-4 producing Env-specific Tfh but not those producing IFN- $\gamma$ favored the development of Env-specific IgG+ GC B cells in NHP challenged with $\mathrm{SHIV}_{\mathrm{AD} 8}$ in the chronic phase [59]. Further research is needed to understand how viral infection modulates the ability of Tfh cells to provide help to B cells, their positioning, Tfh subtype transcriptional differences as well as the factors that contribute to Tfh persistence in the face of chronic viremia.

\section{Role of antigen and immune inflammation}

Broadly neutralizing antibodies have been shown to develop after several years of infection in HIV-1+ individuals, with the first cross-neutralizing antibody responses appearing on average at 2.5 years post- infection [79]. Such bnAbs are characterized by a number of unusual features; they possess high-levels of somatic hypermutation reaching, in some cases, frequencies of $32 \%$ and $20 \%$ in heavy- and kappa- chain V genes respectively [5], extraordinarily long CDR3 antigen-contacting sites [5, 80, 81] and are poly- or autoreactive [82].
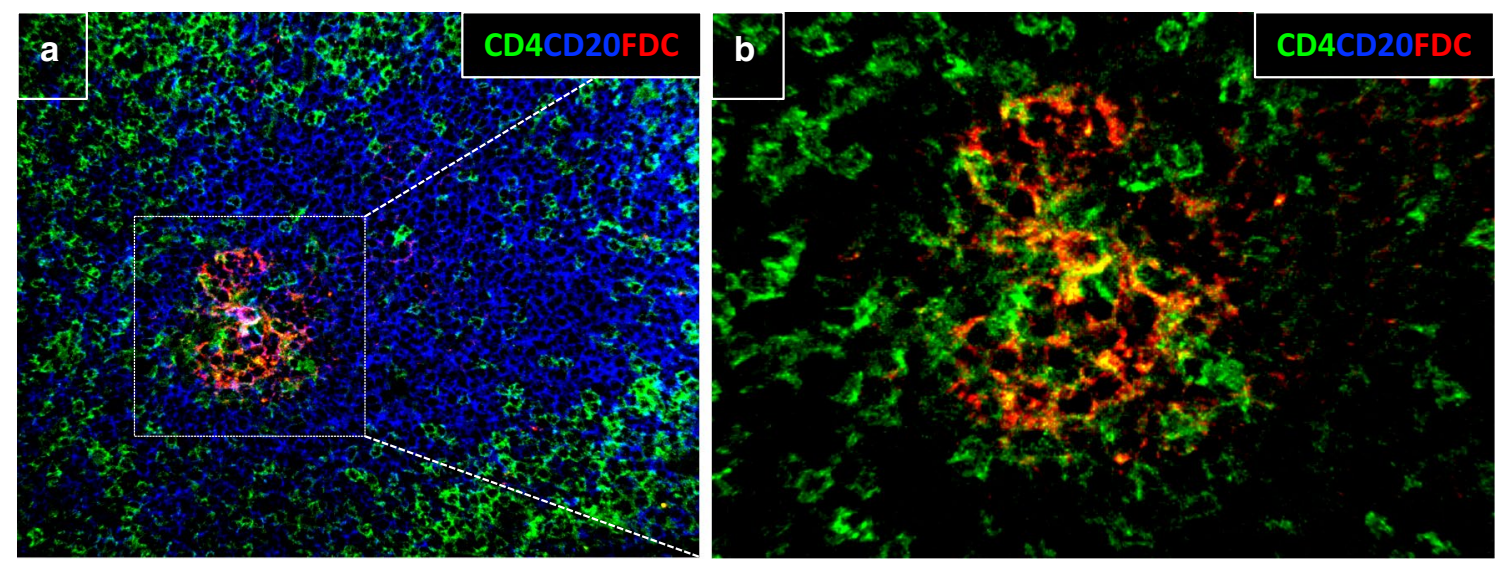

Fig. 2 Convergence of CD4+T cells, B cells and FDC in a B cell follicle. Confocal imaging microscopy showing the convergence of immune populations contributing to the development of bnAbs in a lymph node B cell follicle derived from a HIV-individual. CD4 T cells are shown in green, CD20 in blue and FDCs in red. Images were acquired at $\times 40$ (NA 1.3). Captions are $\mathbf{a} 50 \mu \mathrm{m}$ and $\mathbf{b} 15 \mu \mathrm{m}$ respectively 
Their unique characteristics, potency and breadth arise through a continuous process of $\mathrm{B}$ cell adaptation and affinity maturation which may be fueled by a prolonged exposure to antigen [83, 84]. Antigenic persistence and antigen dose both determine the size and duration of the Tfh response and GC reaction [85] and Tfh cell accumulation in the chronic phase of HIV-1 infection is substantially decreased by ART [51-53]. Therefore, prolonged antigen availability within GCs in the context of HIV-1/ SIV may be contributing to bnAb development by affecting both Tfh and B cell dynamics.

\section{Role of GC B cell quality}

Another hallmark of HIV-1/SIV infection is B cell dysregulation [86]. Several B cell abnormalities manifest during HIV-1 infection including phenotypic changes, polyclonal $\mathrm{B}$ cell activation and hypergammaglobulinaemia, as well as B cell unresponsiveness to T-cell independent and T-cell dependent $\mathrm{B}$ cell activation, all of which might affect the ability of HIV-1 infected individuals to develop bnAbs and respond to therapeutic vaccination or prophylactic vaccination against other infectious diseases such as hepatitis B and influenza [86-91]. The accumulation of Tfh cells in chronic HIV-1 [51, 52] and SIV [53] is associated with expansion of GC B cells and plasma cells. Maturation however into memory B cells is reduced [92]. In addition, B cells from patients with HIV-1 have low expression of the CXCL13 receptor CXCR5 compared with healthy controls and secrete large amounts of CXCL13 upon polyclonal stimulation which could, under physiological conditions alter the homing of B-cells [93]. Currently, there is little information on how B cell impairment affects the bnAb response in HIV-1/ SIV infection. A better understanding of (1) the antigenspecific LN B cell responses, (2) the molecular profile and of GC B cell maturation process and (3) the spatial organization of GC immune reactions in the context of HIV-1/ SIV are warranted in order to successfully design future vaccination strategies.

\section{Role of follicular regulatory T-cells (Tfr)}

FoxP3+ CD4+ Treg cells play an important role in the regulation of $\mathrm{B}$ cell responses as in their absence the levels of circulating antibodies increase [94]. $\mathrm{T}$ follicular regulatory (Tfr) cells, are a subset of FoxP3+ CD4+ Treg cells that localize to the $\mathrm{GC}$ during immune responses to control the magnitude of the response [95]. Phenotypically, Tfr express CXCR5+ alongside the classical Treg marker CD25 [96] but their exact function in the GC, especially in the context of HIV-1 is not yet clear. Given that FoxP3 is expressed in memory non-Treg CD4 T cells too, further phenotypic characterization of LN Tregs is necessary. Under physiological conditions, a skewed presence of Tfr cells in extrafollicular areas compared to follicles has been shown [97]. In chronic HIV-1/SIV infection, the absolute number of Tfr cells within total LN CD4 T cells is increased [98, 99]. However how this may be impacting upon neutralizing B-cell development remains to be found. Studies in LNs of NHP, have shown an inverse correlation of the frequency of LN Tfh cells with Tfr frequency and the avidity of antibodies recognizing the SIV gp120 protein in plasma. Hence, Tfr could act to limit the maturation of antigen-specific responses [100] with bnAb development during HIV-1/SIV infection being favored by a relaxation in the regulatory control of GC antibody production [101, 102]. Further research in NHP LN biopsies and human FNA samples are thus warranted to address in more detail the role of Tfr responses in the expansion of B cells with neutralizing and non-neutralizing reactivities.

\section{Lessons from vaccination}

The realization that many individuals harbor bnAb precursors in their naïve $B$ cell repertoires has reignited the hope that a bnAb-based HIV-1 vaccine might be attainable. Precursor frequency for bnAbs in the naïve repertoire is usually low, with those of the VRC-01 class estimated at $\sim 1$ out of 400,000 naïve B cells [103]. In addition, the affinity of such germline precursors for antigen is also low [104]. Thus, one critical question is how to optimally engage these precursors at tissue-level. The introduction of germline-targeting immunogens, namely immunogens aiming at activating B cells that express specific germline BCRs, represents one strategy to tackle low precursor frequencies $[105,106]$. Furthermore, immunization studies indicate that for optimal vaccine efficacy the following conditions must be met: (1) B cell precursors must be present in the repertoire at sufficient frequencies $[106,107]$ (2) B cell precursors must have sufficient affinity for antigen for recruitment into the GC and competitive success $[106,107]$ (3) B cells and memory B cells must express a favorable antibody class [108] (4) the right structural context and T-B cell stoichiometry must occur in GC for optimal engagement and somatic hypermutation [107] (Table 1).

Tfh cells are central to GC formation and therefore their quantity and quality play a major role. In the absence of $\mathrm{T}$ cells, GCs formed in response to T-independent antigens collapse shortly after compartmentalization into the DZ and LZ [38]. To date, most of the data investigating Tfh quality and phenotype in the context of prophylactic vaccination come from circulating Tfh cells (pTfhs). Although the latter are often used as biomarkers of GC activity the lineage relationship between bona fide Tfh in LN and circulating Tfh is not clear [109-111]. The high heterogeneity of pTfh cell phenotypes and gene 


\begin{tabular}{|c|c|}
\hline Parameter & References \\
\hline \multicolumn{2}{|l|}{ Tfh } \\
\hline Frequency & {$[50]$} \\
\hline Quality & {$[50,52,61,69]$} \\
\hline Phenotype / specificity & {$[50,61,69]$} \\
\hline \multicolumn{2}{|l|}{ B-cells } \\
\hline Precursor frequency & $\begin{array}{l}{[40,94,95,97,} \\
106,107, \\
116]\end{array}$ \\
\hline BCR affinity for antigen & {$[37,40,107]$} \\
\hline Isotype class & [98] \\
\hline Amount of help received by Tfh & {$[36,40,44,52]$} \\
\hline \multicolumn{2}{|l|}{ Antigen } \\
\hline Persistence & {$[76,106]$} \\
\hline Diversity & [69] \\
\hline \multicolumn{2}{|l|}{ Tregs/Tfr } \\
\hline Frequency & {$[53,90,91]$} \\
\hline
\end{tabular}

expression profiles further complicates the interpretation of relevant studies [74, 112, 113]. Of all subsets, PD-1+ CXCR3- CXCR5 + CD4 T cells found in the blood have been found to be the population most related to GC Tfh cells by gene expression, cytokine expression profile and ability to provide help to B cells in vitro [110]. Higher expression of Tfh-associated genes, including CD40L, IL-21 and ICOS has been observed in animals mounting strong neutralizing antibody responses [43] and in the RV144 trial that produced some efficacy in humans, HIV-1-specific IL-21 producing pTfh cells were elevated $[102,110,114,115]$. In addition, HIV-1 infected individuals with strong neutralizing responses harbor higher frequencies of pTfh [102, 110]. However, an association between pTfh and bnAb development is not always present [109]. Further research is needed to delineate the relationship between $\mathrm{GC}$ Tfh, pTfh and bnAbs in the context of prophylactic and therapeutic vaccination.

Antigen presentation and recognition are central to Tfh cell induction [30, 116] Therefore, increasing antigen availability has emerged as a rational approach to enhance Tfh responses for neutralizing antibody production in the context of vaccination [117]. Different strategies are under investigation targeting an effective delivery of immunogens, including (a) the continuous immunogen infusion whereby soluble native antigen degradation is reduced [118, 119], (b) the formation of immuno-complexes and deposition of antigen on monocytes, DCs or FDCs [120, 121], (c) the use of delivery platforms such as nanoparticles, liposomes, viral particles and use of adjuvants that can prolong antigen retention [122]. In parallel, approaches to induce affinity maturation of bnAb-class specific naïve B-cell precursors (ie VRC01 or PGT121class naïve B-cells) by delivering structurally optimized immunogens in sequential immunization protocols are also being tested [104, 123-125]. Combining such protocols with Tfh-boosting strategies will most likely be necessary for optimal vaccine efficacy. The type of primeboost strategy also affects ensuing Tfh responses. Primeboost strategies employing pure DNA instead of protein at priming, have been shown to increase Tfh differentiation, $\mathrm{GC}$ reactivity and antigen-specific antibody titers in mice [126] although to what extend they increase specifically broadly neutralizing antibodies remains to be determined. The interval between priming and boosting is also important for optimal Tfh and B-cell kinetics as an early boost, at the time when Tfh and B-cell maturation are still ongoing, could lead to suboptimal responses [127].

Understanding recall responses is also critical. GC $B$ cell sequencing data indicate that memory B cells actively re-circulate after each immunization and reseed new GCs, with moderately mutated memory B cell lineages being more likely to participate in this reseeding. [128]. In a study by Havenar- Daughton et al, GC B cell frequencies in the draining $\mathrm{LN}$ in response to the final immunization were found to be the most predictive factor for the development of autologous nAbs with the top neutralizers having three fold more responding GC $\mathrm{B}$ cells than animals that only made non-neutralizing $\mathrm{Ab}$ responses [128]. Thus, understanding the recall kinetics of Tfh and B-cells in the context of serial immunizations will be key to developing prophylactic and therapeutic HIV-1 vaccines.

\section{Conclusion}

Much progress has been made over recent years in understanding Tfh cells and their implication in GC B cell responses. It is now clear that Tfh cells are instrumental for the generation of high affinity antibodies. Hence, manipulation of this subset and its microenvironment will be necessary for optimal vaccine efficacy. Tfh cell induction and optimal antigen-specific Tfh- B cell interaction will most likely necessitate a combination of more than one strategy. Deeper insights into the dynamics of Tfh cell induction, function and memory are also warranted. To this end, longitudinal studies in individuals with and without neutralizing activity with fine needle aspirates (FNA) could surpass the current limitations of LN biopsies and the need for complete removal of a $\mathrm{LN}$ at the site of induction. Powerful system immunology approaches, including bioinformatics and nextgeneration sequencing to uncover innate signatures and immune mechanisms that correlate with protection and that can improve vaccine induced long-lived neutralizing 
antibody responses will also be needed to guide the rational development of HIV-1 vaccines. A better understanding of those tissue-specific correlates that lead to robust GC B cell expansion, SHM and neutralization breadth will be key to achieving the goal of sterilizing HIV-1 immunity.

\section{Authors' contributions}

EM and CP discussed the paper, EM wrote the paper, CP and AK edit and approved the paper. All authorsread and approved the final manuscript.

\section{Acknowledgements}

Authors would like to thank the personnel of Tissue Analysis Core at VRC, NIAID for helpful discussions and suggestions.

\section{Competing interests}

The authors declare that they have no competing interests.

\section{Availability of data and materials}

Not applicable.

\section{Consent for publication}

We agree.

Ethics approval and consent to participate

Not applicable.

\section{Funding}

This research was supported by the Intramural Research Program of the Vaccine Research Center, NIAID, National Institutes of Health and CAVD grant (\#OP1032325) from the Bill and Melinda Gates Foundation (R.A.K.).

\section{Publisher's Note}

Springer Nature remains neutral with regard to jurisdictional claims in published maps and institutional affiliations.

Received: 18 May 2018 Accepted: 28 July 2018

Published online: 06 August 2018

\section{References}

1. Hessell AJ, Rakasz EG, Poignard P, Hangartner L, Landucci G, Forthal DN, Koff WC, Watkins DI, Burton DR. Broadly neutralizing human anti-HIV antibody $2 \mathrm{G} 12$ is effective in protection against mucosal SHIV challenge even at low serum neutralizing titers. PLoS Pathog. 2009;5:e1000433.

2. Hessell AJ, Rakasz EG, Tehrani DM, Huber M, Weisgrau KL, Landucci G, Forthal DN, Koff WC, Poignard P, Watkins DI, Burton DR. Broadly neutralizing monoclonal antibodies 2F5 and 4E10 directed against the human immunodeficiency virus type $1 \mathrm{gp} 41$ membrane-proximal external region protect against mucosal challenge by simian-human immunodeficiency virus SHIVBa-L. J Virol. 2010;84:1302-13.

3. Coffin J, Swanstrom R. HIV pathogenesis: dynamics and genetics of viral populations and infected cells. Cold Spring Harb Perspect Med. 2013;3:a012526

4. Watkins DI, Burton DR, Kallas EG, Moore JP, Koff WC. Nonhuman primate models and the failure of the Merck HIV-1 vaccine in humans. Nat Med. 2008;14:617-21.

5. Kwong PD, Mascola JR. Human antibodies that neutralize HIV-1: identification, structures, and B cell ontogenies. Immunity. 2012;37:412-25.

6. Walker LM, Huber M, Doores KJ, Falkowska E, Pejchal R, Julien JP, Wang SK, Ramos A, Chan-Hui PY, Moyle M, et al. Broad neutralization coverage of HIV by multiple highly potent antibodies. Nature. 2011:477:466-70.

7. Lynch RM, Boritz E, Coates EE, DeZure A, Madden P, Costner P, Enama ME, Plummer S, Holman L, Hendel CS, et al. Virologic effects of broadly neutralizing antibody VRC01 administration during chronic HIV-1 infection. Sci Transl Med. 2015;7:319ra206.

8. Scheid JF, Horwitz JA, Bar-On Y, Kreider EF, Lu CL, Lorenzi JC, Feldmann A, Braunschweig M, Nogueira L, Oliveira T, et al. HIV-1 antibody 3BNC117 suppresses viral rebound in humans during treatment interruption. Nature. 2016;535:556-60.

9. Shingai M, Nishimura Y, Klein F, Mouquet H, Donau OK, Plishka R, Buckler-White A, Seaman M, Piatak M Jr, Lifson JD, et al. Antibodymediated immunotherapy of macaques chronically infected with SHIV suppresses viraemia. Nature. 2013;503:277-80.

10. Mascola JR. Passive transfer studies to elucidate the role of antibodymediated protection against HIV-1. Vaccine. 2002;20:1922-5.

11. Mascola JR, Lewis MG, Stiegler G, Harris D, VanCott TC, Hayes D, Louder MK, Brown CR, Sapan CV, Frankel SS, et al. Protection of Macaques against pathogenic simian/human immunodeficiency virus 89.6PD by passive transfer of neutralizing antibodies. J Virol. 1999;73:4009-18.

12. Caskey M, Klein F, Lorenzi JC, Seaman MS, West AP Jr, Buckley N, Kremer G, Nogueira L, Braunschweig M, Scheid JF, et al. Viraemia suppressed in HIV-1-infected humans by broadly neutralizing antibody 3BNC117. Nature. 2015;522:487-91.

13. Cohen YZ, Caskey M. Broadly neutralizing antibodies for treatment and prevention of HIV-1 infection. Curr Opin HIV AIDS. 2018;13:366-73.

14. Gray GE, Allen M, Moodie Z, Churchyard G, Bekker LG, Nchabeleng M, Mlisana K, Metch B, de Bruyn G, Latka MH, et al. Safety and efficacy of the HVTN 503/Phambili study of a clade-B-based HIV-1 vaccine in South Africa: a double-blind, randomised, placebo-controlled test-ofconcept phase 2b study. Lancet Infect Dis. 2011:11:507-15.

15. Hammer SM, Sobieszczyk ME, Janes H, Karuna ST, Mulligan MJ, Grove D, Koblin BA, Buchbinder SP, Keefer MC, Tomaras GD, et al. Efficacy trial of a DNA/rAd5 HIV-1 preventive vaccine. N Engl J Med. 2013;369:2083-92.

16. Nicholson O, DiCandilo F, Kublin J, Sun X, Quirk E, Miller M, Gray G, Pape J, Robertson MN, Mehrotra DV, et al. Safety and immunogenicity of the MRKAd5 gag HIV type 1 vaccine in a worldwide phase 1 study of healthy adults. AIDS Res Hum Retrovir. 2011;27:557-67.

17. Rerks-Ngarm S, Pitisuttithum P, Nitayaphan S, Kaewkungwal J, Chiu J, Paris R, Premsri N, Namwat C, de Souza M, Adams E, et al. Vaccination with ALVAC and AIDSVAX to prevent HIV-1 infection in Thailand. N Engl J Med. 2009:361:2209-20.

18. Moysi E, Padhan K, Fabozzi G, Petrovas C. Novel advances on tissue immune dynamics in HIV/simian immunodeficiency virus: lessons from imaging studies. Curr Opin HIV AIDS. 2018;13:112-8.

19. Moysi E, Estes JD, Petrovas C. Novel imaging methods for analysis of tissue resident cells in HIV/SIV. Curr HIV/AIDS Rep. 2016;13:38-43.

20. Breitfeld D, Ohl L, Kremmer E, Ellwart J, Sallusto F, Lipp M, Forster R. Follicular B helper T cells express CXC chemokine receptor 5, localize to $B$ cell follicles, and support immunoglobulin production. J Exp Med. 2000;192:1545-52.

21. Schaerli P, Willimann K, Lang AB, Lipp M, Loetscher P, Moser B. CXC chemokine receptor 5 expression defines follicular homing $T$ cells with B cell helper function. J Exp Med. 2000;192:1553-62.

22. Ma CS, Deenick EK, Batten M, Tangye SG. The origins, function, and regulation of T follicular helper cells. J Exp Med. 2012;209:1241-53.

23. Kim CH, Rott LS, Clark-Lewis I, Campbell DJ, Wu L, Butcher EC. Subspecialization of CXCR5 + T cells: $B$ helper activity is focused in a germinal center-localized subset of CXCR5+ T cells. J Exp Med. 2001;193:1373-81.

24. Iyer SS, Latner DR, Zilliox MJ, McCausland M, Akondy RS, Penaloza-Macmaster $\mathrm{P}$, Hale JS, Ye L, Mohammed AU, Yamaguchi T, et al. Identification of novel markers for mouse CD4(+) T follicular helper cells. Eur J Immunol. 2013:43:3219-32.

25. Onabajo $\bigcirc 0$, George J, Lewis MG, Mattapallil JJ. Rhesus macaque lymph node PD-1(hi)CD4+ T cells express high levels of CXCR5 and IL-21 and display a CCR7(lo)ICOS+BCl6+T-follicular helper (Tfh) cell phenotype. PLOS ONE. 2013;8:e59758.

26. Crotty S. Do memory CD4 T cells keep their cell-type programming: plasticity versus fate commitment? Complexities of interpretation due to the heterogeneity of memory CD4 T cells, including T follicular helper cells. Cold Spring Harb Perspect Biol. 2018. https://doi. org/10.1101/cshperspect.a032102.

27. Vinuesa CG, Linterman MA, Yu D, MacLennan IC. Follicular helper T cells. Annu Rev Immunol. 2016:34:335-68. 
28. Liu X, Nurieva Rl, Dong C. Transcriptional regulation of follicular T-helper (Tfh) cells. Immunol Rev. 2013;252:139-45.

29. Nurieva Rl, Chung Y, Hwang D, Yang XO, Kang HS, Ma L, Wang YH, Watowich SS, Jetten AM, Tian Q, Dong C. Generation of T follicular helper cells is mediated by interleukin-21 but independent of Thelper 1, 2, or 17 cell lineages. Immunity. 2008;29:138-49.

30. Ballesteros-Tato A, Randall TD. Priming of T follicular helper cells by dendritic cells. Immunol Cell Biol. 2014;92:22-7.

31. Garside P, Ingulli E, Merica RR, Johnson JG, Noelle RJ, Jenkins MK. Visualization of specific $B$ and T lymphocyte interactions in the lymph node. Science. 1998;281:96-9.

32. Okada T, Miller MJ, Parker I, Krummel MF, Neighbors M, Hartley SB, O'Garra A, Cahalan MD, Cyster JG. Antigen-engaged B cells undergo chemotaxis toward the T zone and form motile conjugates with helper T cells. PLoS Biol. 2005;3:e150.

33. Nurieva Rl, Chung Y, Martinez GJ, Yang XO, Tanaka S, Matskevitch TD, Wang YH, Dong C. Bcl6 mediates the development of T follicular helper cells. Science. 2009;325:1001-5.

34. Hiramatsu Y, Suto A, Kashiwakuma D, Kanari H, Kagami S, Ikeda K, Hirose K, Watanabe N, Grusby MJ, Iwamoto I, Nakajima H. c-Maf activates the promoter and enhancer of the IL-21 gene, and TGF-beta inhibits c-Maf-induced IL-21 production in CD4+ T cells. J Leukoc Biol. 2010;87:703-12

35. Belanger S, Crotty S. Dances with cytokines, featuring TFH cells, IL-21, IL-4 and B cells. Nat Immunol. 2016;17:1135-6.

36. Bossaller L, Burger J, Draeger R, Grimbacher B, Knoth R, Plebani A, Durandy A, Baumann U, Schlesier M, Welcher AA, et al. ICOS deficiency is associated with a severe reduction of CXCR5+CD4 germinal center Th cells. J Immunol. 2006;177:4927-32.

37. Brocker T, Gulbranson-Judge A, Flynn S, Riedinger M, Raykundalia C, Lane P. CD4 T cell traffic control: in vivo evidence that ligation of OX40 on CD4T cells by OX40-ligand expressed on dendritic cells leads to the accumulation of CD4 T cells in B follicles. Eur J Immunol. 1999;29:1610-6.

38. Allen CD, Okada T, Cyster JG. Germinal-center organization and cellular dynamics. Immunity. 2007;27:190-202.

39. Shih TA, Meffre E, Roederer M, Nussenzweig MC. Role of BCR affinity in T cell dependent antibody responses in vivo. Nat Immunol. 2002;3:570-5.

40. Paus D, Phan TG, Chan TD, Gardam S, Basten A, Brink R. Antigen recognition strength regulates the choice between extrafollicular plasma cell and germinal center B cell differentiation. J Exp Med. 2006;203:1081-91.

41. Yeh CH, Nojima T, Kuraoka M, Kelsoe G. Germinal center entry not selection of B cells is controlled by peptide-MHCll complex density. Nat Commun. 2018;9:928.

42. Fleire SJ, Goldman JP, Carrasco YR, Weber M, Bray D, Batista FD. B cell ligand discrimination through a spreading and contraction response. Science. 2006;312:738-41.

43. Havenar-Daughton $\mathrm{C}$, Lee $\mathrm{JH}$, Crotty S. Tfh cells and HIV bnAbs, an immunodominance model of the HIV neutralizing antibody generation problem. Immunol Rev. 2017;275:49-61.

44. Petrovas C, Koup RA. T follicular helper cells and HIV/SIV-specific antibody responses. Curr Opin HIV AIDS. 2014;9:235-41.

45. Mesin L, Ersching J, Victora GD. Germinal center B cell dynamics. Immunity. 2016;45:471-82.

46. Ersching J, Efeyan A, Mesin L, Jacobsen JT, Pasqual G, Grabiner BC, Dominguez-Sola D, Sabatini DM, Victora GD. Germinal center selection and affinity maturation require dynamic regulation of mTORC1 kinase. Immunity. 2017;46(1045-1058):e1046.

47. Gitlin AD, Mayer CT, Oliveira TY, Shulman Z, Jones MJ, Koren A, Nussenzweig MC. HUMORAL IMMUNITY.T cell help controls the speed of the cell cycle in germinal center B cells. Science. 2015;349:643-6.

48. Gitlin AD, Shulman Z, Nussenzweig MC. Clonal selection in the germinal centre by regulated proliferation and hypermutation. Nature. 2014:509:637-40.

49. Hong JJ, Amancha PK, Rogers KA, Courtney CL, Havenar-Daughton C, Crotty S, Ansari AA, Villinger F. Early lymphoid responses and germinal center formation correlate with lower viral load set points and better prognosis of simian immunodeficiency virus infection. J Immunol. 2014;193:797-806.

50. Hong JJ, Amancha PK, Rogers K, Ansari AA, Villinger F. Spatial alterations between CD4(+) T follicular helper, B, and CD8(+) T cells during simian immunodeficiency virus infection: T/B cell homeostasis, activation, and potential mechanism for viral escape. J Immunol. 2012;188:3247-56.

51. Lindqvist M, van Lunzen J, Soghoian DZ, Kuhl BD, Ranasinghe S, Kranias G, Flanders MD, Cutler S, Yudanin N, Muller MI, et al. Expansion of HIVspecific T follicular helper cells in chronic HIV infection. J Clin Invest. 2012;122:3271-80.

52. Perreau M, Savoye AL, De Crignis E, Corpataux JM, Cubas R, Haddad EK, De Leval L, Graziosi C, Pantaleo G. Follicular helper T cells serve as the major CD4T cell compartment for HIV-1 infection, replication, and production. J Exp Med. 2013;210:143-56.

53. Petrovas C, Yamamoto T, Gerner MY, Boswell KL, Wloka K, Smith EC, Ambrozak DR, Sandler NG, Timmer KJ, Sun X, et al. CD4 T follicular helper cell dynamics during SIV infection. J Clin Invest. 2012;122:3281-94.

54. van Gils MJ, Sanders RW. Broadly neutralizing antibodies against HIV-1: templates for a vaccine. Virology. 2013;435:46-56.

55. Hraber P, Korber BT, Lapedes AS, Bailer RT, Seaman MS, Gao H, Greene KM, McCutchan F, Williamson C, Kim JH, et al. Impact of clade, geography, and age of the epidemic on HIV-1 neutralization by antibodies. J Virol. 2014;88:12623-43.

56. Moore PL, Williamson C, Morris L. Virological features associated with the development of broadly neutralizing antibodies to HIV-1. Trends Microbiol. 2015;23:204-11.

57. Rademeyer C, Moore PL, Taylor N, Martin DP, Choge IA, Gray ES, Sheppard HW, Gray C, Morris L, Williamson C, Team Hs. Genetic characteristics of HIV-1 subtype $C$ envelopes inducing cross-neutralizing antibodies. Virology. 2007;368:172-81.

58. Piantadosi A, Panteleeff D, Blish CA, Baeten JM, Jaoko W, McClelland RS, Overbaugh J. Breadth of neutralizing antibody response to human immunodeficiency virus type 1 is affected by factors early in infection but does not influence disease progression. J Virol. 2009:83:10269-74.

59. Yamamoto T, Lynch RM, Gautam R, Matus-Nicodemos R, Schmidt SD, Boswell KL, Darko S, Wong P, Sheng Z, Petrovas C, et al. Quality and quantity of TFH cells are critical for broad antibody development in SHIVAD8 infection. Sci Transl Med. 2015;7:298ra120.

60. Landais E, Huang X, Havenar-Daughton C, Murrell B, Price MA, Wickramasinghe L, Ramos A, Bian CB, Simek M, Allen S, et al. Broadly neutralizing antibody responses in a large longitudinal sub-Saharan HIV primary infection cohort. PLoS Pathog. 2016;12:e1005369.

61. Rouers A, Klingler J, Su B, Samri A, Laumond G, Even S, Avettand-Fenoel V, Richetta C, Paul N, Boufassa F, et al. HIV-specific B cell frequency correlates with neutralization breadth in patients naturally controlling HIV-infection. EBioMedicine. 2017;21:158-69.

62. Cubas RA, Mudd JC, Savoye AL, Perreau M, van Grevenynghe J, Metcalf T, Connick E, Meditz A, Freeman GJ, Abesada-Terk G Jr, et al. Inadequate $T$ follicular cell help impairs B cell immunity during HIV infection. Nat Med. 2013;19:494-9.

63. Miles B, Miller SM, Folkvord JM, Kimball A, Chamanian M, Meditz AL, Arends T, McCarter MD, Levy DN, Rakasz EG, et al. Follicular regulatory T cells impair follicular Thelper cells in HIV and SIV infection. Nat Commun. 2015;6:8608.

64. Banga R, Procopio FA, Noto A, Pollakis G, Cavassini M, Ohmiti K, Corpataux JM, de Leval L, Pantaleo G, Perreau M. PD-1(+) and follicular helper T cells are responsible for persistent HIV-1 transcription in treated aviremic individuals. Nat Med. 2016;22:754-61.

65. Boritz EA, Darko S, Swaszek L, Wolf G, Wells D, Wu X, Henry AR, Laboune $\mathrm{F}, \mathrm{Hu}$ J, Ambrozak D, et al. Multiple origins of virus persistence during natural control of HIV infection. Cell. 2016;166:1004-15.

66. Haase AT, Henry K, Zupancic M, Sedgewick G, Faust RA, Melroe H, Cavert W, Gebhard K, Staskus K, Zhang ZQ, et al. Quantitative image analysis of HIV-1 infection in lymphoid tissue. Science. 1996;274:985-9.

67. Heath SL, Tew JG, Tew JG, Szakal AK, Burton GF. Follicular dendritic cells and human immunodeficiency virus infectivity. Nature. 1995;377:740-4.

68. Porichis F, Kaufmann DE. HIV-specific CD4 T cells and immune control of viral replication. Curr Opin HIV AIDS. 2011;6:174-80.

69. Pallikkuth S, Rogers K, Villinger F, Dosterii M, Vaccari M, Franchini G, Pahwa R, Pahwa S. Interleukin-21 administration to rhesus macaques chronically infected with simian immunodeficiency virus increases cytotoxic effector molecules in T cells and NK cells and enhances B cell function without increasing immune activation or viral replication. Vaccine. 2011;29:9229-38. 
70. Vaccari M, Franchini G. T cell subsets in the germinal center: lessons from the macaque model. Front Immunol. 2018;9:348.

71. Wendel BS, Del Alcazar D, He C, Del Rio-Estrada PM, Aiamkitsumrit B Ablanedo-Terrazas Y, Hernandez SM, Ma KY, Betts MR, Pulido L, et al. The receptor repertoire and functional profile of follicular T cells in HIVinfected lymph nodes. Sci Immunol. 2018;3(22):eaan8884. https://doi. org/10.1126/sciimmunol.aan8884

72. Alshekaili J, Chand R, Lee CE, Corley S, Kwong K, Papa I, Fulcher DA, Randall KL, Leiding JW, Ma CS, et al. STAT3 regulates cytotoxicity of human CD57+ CD4+ T cells in blood and lymphoid follicles. Sci Rep. 2018;8:3529.

73. Asrir A, Aloulou M, Gador M, Perals C, Fazilleau N. Interconnected subsets of memory follicular helper T cells have different effector functions. Nat Commun. 2017;8:847.

74. Wong MT, Chen J, Narayanan S, Lin W, Anicete R, Kiaang HT, De Lafaille MA, Poidinger M, Newell EW. Mapping the diversity of follicular helper T cells in human blood and tonsils using high-dimensional mass cytometry analysis. Cell Rep. 2015;11:1822-33.

75. Thacker TC, Zhou X, Estes JD, Jiang Y, Keele BF, Elton TS, Burton GF. Follicular dendritic cells and human immunodeficiency virus type 1 transcription in CD4+ T cells. J Virol. 2009;83:150-8.

76. Hufert FT, van Lunzen J, Janossy G, Bertram S, Schmitz J, Haller O, Racz P, von Laer D. Germinal centre CD4+ T cells are an important site of HIV replication in vivo. AIDS. 1997;11:849-57.

77. Velu V, Mylvaganam GH, Gangadhara S, Hong JJ, lyer SS, Gumber S, Ibegbu CC, Villinger F, Amara RR. Induction of Th1-biased t follicular helper (Tfh) cells in lymphoid tissues during chronic simian immunodeficiency virus infection defines functionally distinct germinal center Tfh cells. J Immunol. 2016;197:1832-42.

78. Havenar-Daughton C, Reiss SM, Carnathan DG, Wu JE, Kendric K, Torrents de la Pena A, Kasturi SP, Dan JM, Bothwell M, Sanders RW, et al. Cytokine-independent detection of antigen-specific germinal center $T$ follicular helper cells in immunized nonhuman primates using a live cell activation-induced marker technique. J Immunol. 2016;197:994-1002.

79. Mikell I, Sather DN, Kalams SA, Altfeld M, Alter G, Stamatatos L. Charac teristics of the earliest cross-neutralizing antibody response to HIV-1. PLOS Pathog. 2011;7:e1001251.

80. Yu L, Guan Y. Immunologic basis for Long HCDR3 s in broadly neutralizing antibodies against HIV-1. Front Immunol. 2014;5:250.

81. McLellan JS, Pancera M, Carrico C, Gorman J, Julien JP, Khayat R, Louder R, Pejchal R, Sastry M, Dai K, et al. Structure of HIV-1 gp120 V1N2 domain with broadly neutralizing antibody PG9. Nature. 2011;480:336-43.

82. Liu M, Yang G, Wiehe K, Nicely NI, Vandergrift NA, Rountree W, Bonsignori M, Alam SM, Gao J, Haynes BF, Kelsoe G. Polyreactivity and autoreactivity among HIV-1 antibodies. J Virol. 2015;89:784-98.

83. Bonsignori M, Zhou T, Sheng Z, Chen L, Gao F, Joyce MG, Ozorowski G, Chuang GY, Schramm CA, Wiehe K, et al. Maturation pathway from germline to broad HIV-1 neutralizer of a CD4-mimic antibody. Cell. 2016;165:449-63.

84. Sather DN, Armann J, Ching LK, Mavrantoni A, Sellhorn G, Caldwell Z, Yu X, Wood B, Self S, Kalams S, Stamatatos L. Factors associated with the development of cross-reactive neutralizing antibodies during human immunodeficiency virus type 1 infection. J Virol. 2009;83:757-69.

85. Baumjohann D, Preite S, Reboldi A, Ronchi F, Ansel KM, Lanzavecchia A, Sallusto F. Persistent antigen and germinal center B cells sustain T follicular helper cell responses and phenotype. Immunity. 2013;38:596-605.

86. Moir S, Fauci AS. Insights into B cells and HIV-specific B-cell responses in HIV-infected individuals. Immunol Rev. 2013;254:207-24.

87. Cagigi A, Nilsson A, Pensieroso S, Chiodi F. Dysfunctional B-cell responses during HIV-1 infection: implication for influenza vaccination and highly active antiretroviral therapy. Lancet Infect Dis. 2010;10:499-503.

88. De Milito A. B lymphocyte dysfunctions in HIV infection. Curr HIV Res. 2004;2:11-21.

89. De Milito A, Nilsson A, Titanji K, Thorstensson R, Reizenstein E, Narita M, Grutzmeier S, Sonnerborg A, Chiodi F. Mechanisms of hypergammaglobulinemia and impaired antigen-specific humoral immunity in HIV-1 infection. Blood. 2004;103:2180-6.
90. Lane HC, Masur H, Edgar LC, Whalen G, Rook AH, Fauci AS. Abnormalities of B-cell activation and immunoregulation in patients with the acquired immunodeficiency syndrome. N Engl J Med. 1983;309:453-8.

91. Shirai A, Cosentino M, Leitman-Klinman SF, Klinman DM. Human immunodeficiency virus infection induces both polyclonal and virus-specific B cell activation. J Clin Invest. 1992;89:561-6.

92. Colineau L, Rouers A, Yamamoto T, Xu Y, Urrutia A, Pham HP, Cardinaud S, Samri A, Dorgham K, Coulon PG, et al. HIV-infected spleens present altered follicular helper T cell (Tfh) subsets and skewed B cell maturation. PLOS ONE. 2015;10:e0140978.

93. Cagigi A, Mowafi F, Phuong Dang LV, Tenner-Racz K, Atlas A, Grutzmeier $\mathrm{S}$, Racz P, Chiodi F, Nilsson A. Altered expression of the receptor-ligand pair CXCR5/CXCL13 in B cells during chronic HIV-1 infection. Blood. 2008:112:4401-10.

94. Eggena MP, Barugahare B, Jones N, Okello M, Mutalya S, Kityo C, Mugyenyi $\mathrm{P}, \mathrm{CaO} \mathrm{H}$. Depletion of regulatory T cells in HIV infection is associated with immune activation. J Immunol. 2005;174:4407-14.

95. Linterman MA, Pierson W, Lee SK, Kallies A, Kawamoto S, Rayner TF, Srivastava M, Divekar DP, Beaton L, Hogan JJ, et al. Foxp3+ follicular regulatory $T$ cells control the germinal center response. Nat Med. 2011;17:975-82.

96. Maceiras AR, Fonseca VR, Agua-Doce A, Graca L. T follicular regulatory cells in mice and men. Immunology. 2017;152:25-35.

97. Amodio D, Cotugno N, Macchiarulo G, Rocca S, Dimopoulos Y, Castrucci MR, De Vito R, Tucci FM, McDermott AB, Narpala S, et al. Quantitative multiplexed imaging analysis reveals a strong association between immunogen-specific B cell responses and tonsillar germinal center immune dynamics in children after influenza vaccination. J Immunol. 2018;200:538-50.

98. Andersson J, Boasso A, Nilsson J, Zhang R, Shire NJ, Lindback S, Shearer GM, Chougnet CA. The prevalence of regulatory T cells in lymphoid tissue is correlated with viral load in HIV-infected patients. J Immunol. 2005:174:3143-7.

99. Estes JD, Li Q, Reynolds MR, Wietgrefe S, Duan L, Schacker T, Picker LJ, Watkins DI, Lifson JD, Reilly $C$, et al. Premature induction of an immunosuppressive regulatory $T$ cell response during acute simian immunodeficiency virus infection. J Infect Dis. 2006;193:703-12.

100. Blackburn MJ, Zhong-Min M, Caccuri F, McKinnon K, Schifanella L, Guan Y, Gorini G, Venzon D, Fenizia C, Binello N, et al. Regulatory and helper follicular T cells and antibody avidity to simian immunodeficiency virus glycoprotein 120. J Immunol. 2015;195:3227-36.

101. Borrow P, Moody MA. Immunologic characteristics of HIV-infected individuals who make broadly neutralizing antibodies. Immunol Rev. 2017;275:62-78.

102. Moody MA, Pedroza-Pacheco I, Vandergrift NA, Chui C, Lloyd KE, Parks R, Soderberg KA, Ogbe AT, Cohen MS, Liao HX, et al. Immune perturbations in HIV-1-infected individuals who make broadly neutralizing antibodies. Sci Immunol. 2016;1:aag0851.

103. Jardine JG, Kulp DW, Havenar-Daughton C, Sarkar A, Briney B, Sok D Sesterhenn F, Ereno-Orbea J, Kalyuzhniy O, Deresa I, et al. HIV-1 broadly neutralizing antibody precursor $\mathrm{B}$ cells revealed by germline-targeting immunogen. Science. 2016;351:1458-63.

104. Jardine J, Julien JP, Menis S, Ota T, Kalyuzhniy O, McGuire A, Sok D, Huang PS, MacPherson S, Jones M, et al. Rational HIV immunogen design to target specific germline B cell receptors. Science. 2013;340:711-6.

105. Stamatatos L, Pancera M, McGuire AT. Germline-targeting immunogens Immunol Rev. 2017;275:203-16.

106. Dosenovic P, Kara EE, Pettersson AK, McGuire AT, Gray M, Hartweger $H$, Thientosapol ES, Stamatatos L, Nussenzweig MC. Anti-HIV-1 B cell responses are dependent on $B$ cell precursor frequency and antigenbinding affinity. Proc Natl Acad Sci U S A. 2018;115:4743-8.

107. Abbott RK, Lee JH, Menis S, Skog P, Rossi M, Ota T, Kulp DW, BhulIar D, Kalyuzhniy O, Havenar-Daughton C, et al. Precursor frequency and affinity determine B cell competitive fitness in germinal centers, tested with germline-targeting HIV vaccine immunogens. Immunity. 2018;48(133-146):e136

108. Dogan I, Bertocci B, Vilmont V, Delbos F, Megret J, Storck S, Reynaud CA, Weill JC. Multiple layers of B cell memory with different effector functions. Nat Immunol. 2009;10:1292-9. 
109. Boswell KL, Paris R, Boritz E, Ambrozak D, Yamamoto T, Darko S, Wloka K, Wheatley A, Narpala S, McDermott A, et al. Loss of circulating CD4 T cells with $B$ cell helper function during chronic HIV infection. PLoS Pathog. 2014;10:e1003853.

110. Locci M, Havenar-Daughton C, Landais E, Wu J, Kroenke MA, Arlehamn CL, Su LF, Cubas R, Davis MM, Sette A, et al. Human circulating PD-1+CXCR3-CXCR5+ memory Tfh cells are highly functional and correlate with broadly neutralizing HIV antibody responses. Immunity. 2013:39:758-69.

111. He J, Tsai LM, Leong YA, Hu X, Ma CS, Chevalier N, Sun X, Vandenberg K, Rockman S, Ding Y, et al. Circulating precursor CCR7(lo)PD-1(hi) CXCR5(+) CD4(+) T cells indicate Tfh cell activity and promote antibody responses upon antigen reexposure. Immunity. 2013;39:770-81.

112. Schmitt N, Bentebibel SE, Ueno H. Phenotype and functions of memory Tfh cells in human blood. Trends Immunol. 2014;35:436-42.

113. Schmitt $\mathrm{N}$, Ueno H. Blood Tfh cells come with colors. Immunity. 2013;39:629-30.

114. Chahroudi A, Silvestri G. HIV and Tfh cells: circulating new ideas to identify and protect. Immunity. 2016;44:16-8.

115. Schultz BT, Teigler JE, Pissani F, Oster AF, Kranias G, Alter G, Marovich M, Eller MA, Dittmer U, Robb ML, et al. Circulating HIV-specific interleukin-21(+)CD4(+) T cells represent peripheral Tfh cells with antigendependent helper functions. Immunity. 2016:44:167-78.

116. Deenick EK, Chan A, Ma CS, Gatto D, Schwartzberg PL, Brink R, Tangye $S G$. Follicular helper $T$ cell differentiation requires continuous antigen presentation that is independent of unique B cell signaling. Immunity 2010;33:241-53.

117. Linterman MA, Hill DL. Can follicular helper T cells be targeted to improve vaccine efficacy? [version 1; referees: 3 approved]. F1000Research. 2016;5(F1000 Faculty Rev):88. https://doi.org/10.12688/f1000 research.7388.1.

118. Pauthner M, Havenar-Daughton C, Sok D, Nkolola JP, Bastidas R, Boopathy AV, Carnathan DG, Chandrashekar A, Cirelli KM, Cottrell CA, et al. Elicitation of robust tier 2 neutralizing antibody responses in nonhuman primates by hiv envelope trimer immunization using optimized approaches. Immunity. 2017;46(1073-1088):e1076.

119. Tam HH, Melo MB, Kang M, Pelet JM, Ruda VM, Foley MH, Hu JK, Kumari S, Crampton J, Baldeon AD, et al. Sustained antigen availability during germinal center initiation enhances antibody responses to vaccination. Proc Natl Acad Sci U S A. 2016;113:E6639-48.

120. Flamar AL, Contreras V, Zurawski S, Montes M, Dereuddre-Bosquet N, Martinon F, Banchereau J, Le Grand R, Zurawski G, Levy Y. Delivering HIV Gagp24 to DCIR induces strong antibody responses in vivo. PLoS ONE. 2015;10:e0135513.

121. Park HY, Tan PS, Kavishna R, Ker A, Lu J, Chan CEZ, Hanson BJ, MacAry PA Caminschi l, Shortman K, et al. Enhancing vaccine antibody responses by targeting Clec9A on dendritic cells. NPJ Vaccines. 2017;2:31.

122. Gao Y, Wijewardhana C, Mann JFS. Virus-like particle, liposome, and polymeric particle-based vaccines against HIV-1. Front Immunol. 2018;9:345.

123. Escolano A, Steichen JM, Dosenovic P, Kulp DW, Golijanin J, Sok D, Freund NT, Gitlin AD, Oliveira T, Araki T, et al. Sequential immunization elicits broadly neutralizing anti-HIV-1 antibodies in Ig knockin mice. Cell. 2016;166(1445-1458):e1412.

124. Briney B, Sok D, Jardine JG, Kulp DW, Skog P, Menis S, Jacak R, Kalyuzhniy O, de Val N, Sesterhenn F, et al. Tailored Immunogens direct affinity maturation toward HIV neutralizing antibodies. Cell. 2016;166(1459-1470):e1411.

125. Tian M, Cheng C, Chen X, Duan H, Cheng HL, Dao M, Sheng Z, Kimble $M$, Wang $L$, Lin S, et al. Induction of HIV neutralizing antibody lineages in mice with diverse precursor repertoires. Cell. 2016;166(1471-1484):e1418.

126. Hollister K, Chen Y, Wang S, Wu H, Mondal A, Clegg N, Lu S, Dent A. The role of follicular helper T cells and the germinal center in HIV-1 gp120 DNA prime and gp120 protein boost vaccination. Hum Vaccin Immunother. 2014;10:1985-92.

127. Sallusto F, Lanzavecchia A, Araki K, Ahmed R. From vaccines to memory and back. Immunity. 2010;33:451-63.

128. Havenar-Daughton C, Carnathan DG, Torrents de la Pena A, Pauthner M, Briney B, Reiss SM, Wood JS, Kaushik K, van Gils MJ, Rosales SL, et al. Direct probing of germinal center responses reveals immunological features and bottlenecks for neutralizing antibody responses to HIV Env trimer. Cell Rep. 2016;17:2195-209.
Ready to submit your research? Choose BMC and benefit from:

- fast, convenient online submission

- thorough peer review by experienced researchers in your field

- rapid publication on acceptance

- support for research data, including large and complex data types

- gold Open Access which fosters wider collaboration and increased citations

- maximum visibility for your research: over $100 \mathrm{M}$ website views per year

At $\mathrm{BMC}$, research is always in progress.

Learn more biomedcentral.com/submissions 